\title{
Ávöxtun íslenskra hlutabréfa í aðdraganda og kjölfar hruns
}

\author{
Gylfi Magnússon ${ }^{1}$
}

\begin{abstract}
Ágrip
Í fyrri rannsókn höfundar var sýnt fram á að ávöxtun hlutabréfa, sem skráð eru í Kauphöll Íslands, hafði nokkur sérkenni um mánaðamót, ársfjórðungamót og áramót. Hlutabréf hækkuðu að jafnaði umtalsvert í verði síðasta viðskiptadag mánaðar en lækkuðu svo aftur fyrsta viðskiptadag mánaðar á árunum frá 2000 til 2006. Pessi rannsókn er framhaldsrannsókn par sem skoðað er hvort sömu einkenni komu einnig fram í aðdraganda hruns fjármálamarkaðarins, árin 2007 og 2008, eða á endurreistum fjármálamarkaði eftir hrun. Í ljós kemur að svo virðist vera pegar síðustu misserin fyrir hrun eru skoðuð en einungis veikar ef nokkrar vísbendingar eru um slíkt mynstur eftir hrun. Pá er viðfangsefnið einnig skoðað í ljósi viðamikilla gagna sem birst hafa eftir hrun um fjármögnun hlutabréfakaupa á íslenska markaðnum og kerfisbundin kaup fjármálafyrirtækja á eigin bréfum og hlutabréfum tengdra fyrirtækja.
\end{abstract}

\begin{abstract}
A previous study showed that the return on stocks that are listed on the Icelandic stock exchange had a few unusual characteristics in the trading days around the turn-of-themonth, quarter or year. Stock prices rose on average significantly in the last trading day of the month and then declined again in the first trading day of the month in the period 2000 until 2006. This is a follow-up study that examines whether the same pattern existed in the years 2007 and 2008, the period leading up to the collapse of the Icelandic banking system, and in the period since the collapse. The data shows that the pattern seems to have continued until the collapse but there are only weak if any signs of the pattern after the collapse. The topic is also analysed using extensive data that has been made public after the collapse on the financing of stock purchases in the Icelandic market and systematic purchases by financial institutions of their own stock and that of related companies.
\end{abstract}

JEL-flokkun: G12, G14

Lykilhugtök: hlutabréfaverđ, skilvirkni, mánaðamót, íslenskur hlutabréfamarkaður, fjármálakrísa

\footnotetext{
${ }^{1}$ Höfundur er dósent í viðskiptafræðideild Háskóla Íslands. Höfundur vill pakka starfsfólki Kauphallar Íslands (Nasdaq OMX Íslandi) fyrir aðstoð við gagnaöflun og ritrýni fyrir gagnlegar athugasemdir og ábendingar.

2 Í pessari rannsókn er ekki sérstaklega horft til ávöxtunar eftir vikudögum en benda má á að í 


\section{Inngangur}

Fyrri rannsókn (Gylfi Magnússon, 2006) sýndi fram á að íslenski hlutabréfamarkaðurinn skar sig talsvert úr öðrum mörkuðum pegar verðpróun hlutabréfa um mánaðamót var skoðuð. Sérstaðan var skýrust um ársfjórðunga- eða áramót. Verð hlutabréfa hækkaði að jafnaði skömmu fyrir slík tímamót en lækkaði svo aftur í kjölfarið. Pessi niðurstaða var vísbending um hugsanlega markaðsmisnotkun par sem verð hlutabréfa er hækkað með viðskiptum í lok tímabils til að bæta stöðu eigenda á pappírnum í uppgjöri. Pó var athyglisvert að hækkun síðasta viðskiptadags fyrir uppgjör kom alla jafna fram að morgni dags en ekki skömmu fyrir lokun viðskipta.

Fyrrnefnd rannsókn byggði á peim gögnum, sem pá voru aðgengileg, um verð hlutabréfa, hlutabréfavísitölur, veltu og fleira frá upphafi til ársloka 2006. Síðan hefur margt gerst og ítarleg gögn orðið aðgengileg, sem ekki voru pað áður, er varpa nýju ljósi á rannsóknarviðfangið.

Pótt alvarlegar áhyggjur ýmissa aðila af íslenska fjármálakerfinu yrðu opinberar pegar árið 2006 pá hækkaði hlutabréfaverð almennt á Íslandi fram í júlí 2007. Pá hófst lækkunarhrina sem stóð allt par til fjármálakerfið hrundi í október 2008. Lokað var fyrir öll viðskipti á íslenska hlutabréfamarkaðinum í örfáa daga eftir hrunið en síðan hófust viðskipti á ný. Hlutabréfamarkaðurinn hefur pó síðan verið með allt öðrum brag en árin á undan, örfá fyrirtæki skráð, markaðsverðmæti peirra lítið og velta brot af pví sem hún var pegar mest var.

Með pessari rannsókn er einkum ætlað að kanna annars vegar hvort pau sérkenni í ávöxtun, sem fyrri rannsókn leiddi í ljós, voru einnig til staðar pegar alvarlega var farið að fjara undan íslenska hlutabréfamarkaðinum. Hins vegar er skoðað hvort pau koma einnig fram eftir hrun fjármálakerfisins. Petta er m.a. áhugavert í ljósi pess að gögn rannsóknarnefndar Alpingis hafa sýnt fram á kerfisbundnar tilraunir fjármálafyrirtækja til að hafa áhrif á verð hlutabréfa, sérstaklega eigin bréfa, í aðdraganda hrunsins með pví að leitast við að purrka upp framboð hlutabréfanna á markaði og endurselja síðan í stórum skömmtum til valinna fjárfesta, eins og rakið er í kafla 4 hér á eftir.

\section{Fyrri rannsóknir}

Fræðimenn og pátttakendur á fjármálamörkuðum hafa lengi leitað að sérkennilegum verðmynstrum. M.a. hafa margir ritað um ýmsar tegundir dagatalsáhrifa, p.e. sérkenna í verðpróun sem virðast tengjast einstökum dögum, bæði vikudögum og frídögum, og mánuðum eða mánaðamótum. Virðist mega rekja slík skrif a.m.k. aftur til 1930 en pá var m.a. fjallað um tiltölulega lága ávöxtun bandarískra hlutabréfa á mánudögum í bók (Kelly, 1930, sjá einnig Maberly, 1995). Fields (1931) birti ári síðar rannsókn sem skoðaði ávöxtun Dow Jones vísitölunnar á laugardögum. Kelly byggði niðurstöður sínar einnig á skoðun á Dow Jones vísitölunni en hún hefur verið reiknuð út allt frá árinu 1896 og var pví oft horft til hennar í fyrstu rannsóknum á hlutabréfamörkuðum. Pettengill (2003) fjallar ítarlega um sögu rannsókna á mánudagsáhrifum. Rannsakendur hafa ekki sagt skilið við mánudagsáhrifin pótt meira en áttatíu ár séu liðin frá pví fyrst var ritað um pau. Meðal nýlegra rannsókna má 
nefna (Chee-Jiun og Ye, 2011) sem leita slíkra áhrifa á mörkuðum í Suður-Afríku og nágrannalöndum. ${ }^{2}$

Gylfi Magnússon (2006) rakti ýmsar fyrri erlendar rannsóknir á sérkennilegri verðpróun hlutabréfa um mánaðamót. Er vísað í pá grein um frekara sögulegt yfirlit. Mikið hefur verið skrifað um efnið erlendis og enn er verið að. Meðal nýlegra rannsókna má nefna McConnell og Xu (2008). Peir skoðuðu ávöxtun hlutabréfa í Bandaríkjunum á tímabilinu 1926 til 2005 og komust að peirri niðurstöðu að megnið af ávöxtuninni hefði orðið til dagana í kringum mánaðamót. Peir skoða jafnframt 35 önnur lönd og sjá svipaða niðurstöðu í 31 landanna. McConnell og Xu sjá merki um óvenjuháa ávöxtun bæði dagana fyrir og eftir mánaðamót. Sharma og Narayan (2011) komast að svipaðri niðurstöðu fyrir 560 bandarísk hlutafélög. Раð er einnig sama niðurstaða og Gylfi Magnússon (2006) fékk fyrir erlenda hlutabréfamarkaði.

Ekki sjást hins vegar merki erlendis um hækkun í aðdraganda mánaðamóta, sem gengur til baka strax eftir mánaðamót, eins og fannst fyrir íslenska markaðinn. ${ }^{3}$ Meðal pess, sem stungið hefur verið upp á sem skýringu á peim niðurstöðum, sem McConnell og Xu og margir fleiri hafa fundið fyrir erlenda markaði, er hve algengt er að ýmiss konar pjóðhagsstærðir séu birtar um mánaðamót, sérstaklega í Bandaríkjunum. Pað skýrir pó ekki pað mynstur sem fannst fyrir íslenska markaðinn. Fleiri skýringar hafa verið nefndar sem raktar eru í fyrri rannsókn höfundar.

Meðal fyrri rannsókna á íslenskum hlutabréfamarkaði má nefna Stefán B. Gunnlaugsson (2003) sem kannaði hvort munur væri á ávöxtun Úrvalsvísitölunnar íslensku eftir mánuðum eða vikudögum og hvort hún væri óvenjuleg rétt fyrir eða eftir frídaga vegna hátíða. Byggt var á daglegum breytingum vísitölunnar frá áramótum 1992-1993 til maí 2003.

Niðurstöðurnar voru að ávöxtun íslenskra hlutabréfa hefði verið jákvæð dagana fyrir hátíðir en neikvæð rétt á eftir. Munurinn hefði pó verið lítill fyrir og eftir jól. Áhrif áramóta voru mest en síðasta viðskiptadag ársins var ávöxtun um 13 sinnum meiri en aðra daga að jafnaði. Munurinn á ávöxtun fyrir og eftir hátíðir reyndist tölfræðilega marktækur.

Einnig fjölluðu vikuritið Vísbending (2006) og Kauphallartíðindi (2006) um hækkun Úrvalsvísitölunnar eftir annars vegar pví hvort um fyrri eða síðari hluta ársfjórðungs var að ræða og hins vegar eftir vikudögum og mánaðardögum. Fram kemur að vísitalan virðist hækka örlítið meira að meðaltali á dag eftir pví sem líður á vikuna og aðeins meira fyrri hluta ársfjórðungs en síðari hluta. Pegar mánaðardagar eru skoðaðir virðist sömuleiðis örlítil leitni upp á við pegar líður á mánuðinn.

Fyrrnefndar greinar í Vísbendingu og Kauphallartíđindum vísa báðar til orðróms um markaðsmisnotkun á Íslandi. Fleiri dæmi má finna í fjölmiðlum frá pví fyrir árið 2007 par sem rætt er um slíkan orðróm. Pau dæmi eru pó ekki mörg. Umræða um markaðsmisnotkun á Íslandi hefur margfaldast frá hruni fjármálakerfisins en verður ekki rakin hér umfram pað sem fram kemurí kafla 4.

2 Í pessari rannsókn er ekki sérstaklega horft til ávöxtunar eftir vikudögum en benda má á að í (Gylfi Magnússon, 2006) kom fram að ávöxtun á íslenska hlutabréfamarkaðinum árin 2000-2006 hefði verið lægst að jafnaði mánudaga og priðjudaga $(-0,01 \%)$ en hæst fimmtudaga $(0,20 \%)$ og föstudaga $(0,24 \%)$.

${ }^{3}$ Í einungis einu landi sem McConnell og Xu skoðuðu kom fram sama mynstur og á Íslandi, p.e. hækkun fyrir mánaðamót og lækkun strax eftir mánaðamót. Pað var í Kólumbíu. Lækkun fyrsta dag mánaðarins par var pó ekki tölfræðilega marktæk. 


\section{Gögn}

Við rannsókn pessa var einkum stuðst við gögn frá Kauphöll Íslands (Nasdaq OMX Íslandi). Skoðuð voru gögn um Úrvalsvísitöluna (ICEX-15), bæði með og án arðs, frá upphafi, p.e. frá ársbyrjun 1993, og pangað til hætt var að reikna vísitöluna út í lok júní 2009. Jafnframt voru skoðuð gögn um vísitöluna sem leysti Úrvalsvísitöluna af hólmi, OMXI6ISK, frá pví tekið var að reikna hana í ársbyrjun 2009 til byrjunar ársins 2012. Pá fengust gögn um dagslokaverð frá upphafi til janúar 2012 allra fyrirtækja sem skráð voru í Kauphöllina í upphafi árs 2006 eða fengu skráningu á pví ári eða síðar. Jafnframt var stuðst við gögn frá rannsóknarnefnd Alpingis.

\section{Markaðsmisnotkun á Íslandi}

Markaðsmisnotkun er óheimil á Íslandi líkt og í öðrum vestrænum löndum. Nokkur dæmi um meinta markaðsmisnotkun komu upp fyrr á árum. Gylfi Magnússon (2006) rekur pau helstu. Eftir hrun íslenska fjármálakerfisins í október 2008 hefur málum par sem rökstuddur grunur er um markaðsmisnotkun fjölgað til muna. Ekki hefur pó verið dæmt nema í einu máli pegar petta er ritað. Hæstiréttur dæmdi í mars 2011 tvo fyrrverandi starfsmenn annars vegar Kauppings og hins vegar Rekstrarfélags Kauppings í sex mánaða fangelsi fyrir að hafa lagt fram kauptilboð í skuldabréf Exista í peim tilgangi að hafa áhrif á dagslokaverð bréfanna (Hæstaréttardómur í máli nr. 52/2010).

Skýrsla rannsóknarnefndar Alpingis (Páll Hreinsson, Sigríður Benediktsdóttir og Tryggvi Gunnarsson, 2010) [hér eftir RNA] birtir umfangsmikil gögn, bæði talnaefni og fleira, par sem leidd eru mjög sterk rök að pví að viðamikil markaðsmisnotkun hafi tíðkast á íslenska hlutabréfamarkaðinum um árabil fyrir hrun fjármálamarkaðarins. Sérstaklega eru gögnin skýr hvað varðar viðleitni viðskiptabankanna priggja til að hafa áhrif á verð eigin bréfa til hækkunar eftir að pau voru tekin að lækka eftir mitt ár 2007. RNA rekur viðskipti bankanna með eigin bréf í löngu máli og birtir mikið af talnaefni sem ekki verður rakið hér, sjá sérstaklega kafla 12.6 í 4 . bindi.

Pannig bendir RNA á að bankarnir prír hafi allir keypt eigin bréf í miklum mæli á hlutabréfamarkaði síðustu starfsár peirra en mun sjaldnar selt bréf í Kauphöllinni. Bréfin hafi hins vegar verið seld í stórum skömmtum utan Kauphallarinnar, iðulega í viðskiptum, sem viðkomandi banki fjármagnaði að verulegu leyti með veði í bréfunum. ${ }^{4}$ Í pessu samhengi er sérstaklega athyglisvert að um $40 \%$ hlutabréfa stóru bankanna priggja voru veðsett síðustu tvö árin fyrir hrun (skýrsla RNA, 2. bindi bls. 105), sem sýnir skýrt að staða eigenda var mjög voguð og að framboð af lánsfé skipti miklu fyrir spurn eftir íslenskum hlutabréfum. ${ }^{5}$ Mynd 1

${ }^{4}$ Pótt fjármögnun íslensku bankanna á kaupum eigin hlutabréfa hafi að pví er virðist verið mun umfangsmeiri en dæmi eru um annars staðar pá hafa pó á undanförnum árum komið fram einstök dæmi um hið sama frá öðrum löndum. Má par nefna Anglo Irish Bank á Írlandi, sem fjármagnaði kaup tíu fjárfesta á eigin bréfum fyrir um 450 milljónir evra, og Dexia í Belgíu, sem fjármagnaði í gegnum dótturfélag kaup tveggja hluthafa, sem áttu um 35\% hlutafjár í bankanum, á hlutabréfum í bankanum fyrir allt að 1,5 milljarða evra. Dexia lánaði gegn veði í eigin bréfum.

${ }^{5}$ Með veðsetningu er hér átt við formlega veðsetningu sem skráð er í kerfi Verðbréfaskráningar Íslands. Hafa má í huga að í einhverjum tilfellum var lánað til hlutabréfakaupa par sem bréfin voru í reynd veð fyrir láninu pótt pau væru pað ekki formlega. Pví var hægt að ná fram með samningi par sem lántakinn skuldbatt sig til að selja bréfin ekki án leyfis lánveitanda (eða seldi bréfin ekki öðrum en lánveitanda) og að afrakstur af sölu rynni til lánveitanda, upp að peirri upphæð, sem lántaki skuldaði. 


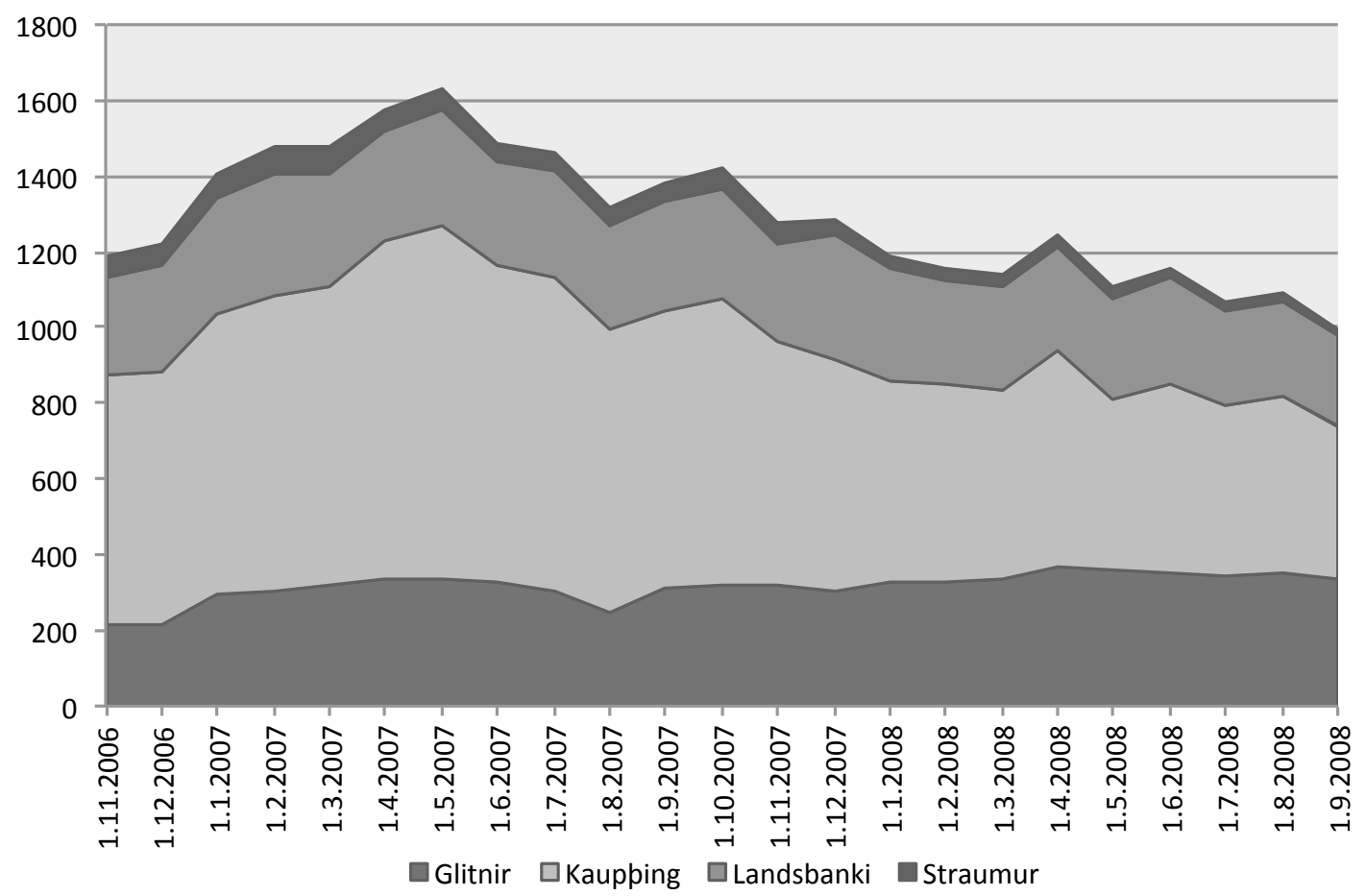

Mynd 1. Verðmæti hlutabréfa í handveði hjá bönkunum Milljarðar króna. Heimild: RNA og útreikningar höfundar.

sýnir heildarverðmæti hlutabréfa sem fjórir stærstu bankarnir (Kaupping, Landsbanki, Glitnir og Straumur) höfðu að handveði fyrir hrun. Hafa ber í huga við skoðun myndarinnar að skráð markaðsverð íslenskra hlutabréfa hækkaði almennt fram á mitt ár 2007 en lækkaði eftir раð. Раð hafði lækkað alls um meira en helming frá hæsta gildi í júlí 2007 pegar bankarnir féllu. Mynd 2 sýnir annan flöt á sama máli, hlutfall hlutabréfa í bönkunum og tveimur stórum eigendum banka, FL Group og Exista, sem voru veðsett í kerfi Verðbréfaskráningar Íslands.

Við blasir jafnframt skv. gögnum RNA að hver banki hafði aðra stefnu varðandi eigin bréf en bréf hinna bankanna. Hver banki keypti og seldi nokkurn veginn jöfnum höndum bréf hinna bankanna á hlutabréfamarkaði. Pá bendir RNA á að bankarnir hafi tapað umtalsverðu fé á að reyna að halda uppi verði bréfa sinna pví að peir hefðu síendurtekið neyðst til að selja bréf á lægra verði en peir höfðu keypt pau á. •að hefði ekki verið niðurstaðan úr eðlilegri viðskiptavakt, jafnvel pótt verð bréfanna hefði almennt farið lækkandi.

Niðurstaða RNA er að bankarnir hafi með pessum hætti skekkt pá mynd sem aðrir hluthafar höfðu af verðmæti bréfa sinna, p.e. látið líta út fyrir að pau væru verðmeiri en pau voru í raun. Rannsóknarnefndin segir m.a.: „Rannsóknarnefndin telur pví að bankarnir hafi allir reynt að kalla fram óeðlilega eftirspurn eftir hlutabréfum í sjálfum sér og notað til pess pað svigrúm sem hægt var skapa með viðskiptum deilda eigin viðskipta." (RNA, 4. bindi, bls. 63)

Jafnframt skoðaði RNA viðskipti banka með hlutabréf í félögum sem voru eigendur stórs hlutar viðkomandi banka eða tengdust stórum eigendum. Par kemur einnig fram að bankarnir héldu að nokkru marki uppi spurn eftir bréfunum á markaði, með kaupum umfram sölu, pótt pað hafi ekki verið gert með jafnafgerandi hætti og með bréf í bönkunum sjálfum. Ályktun RNA um pessi viðskipti er pó varfærin. Nefndin segir um petta efni: 


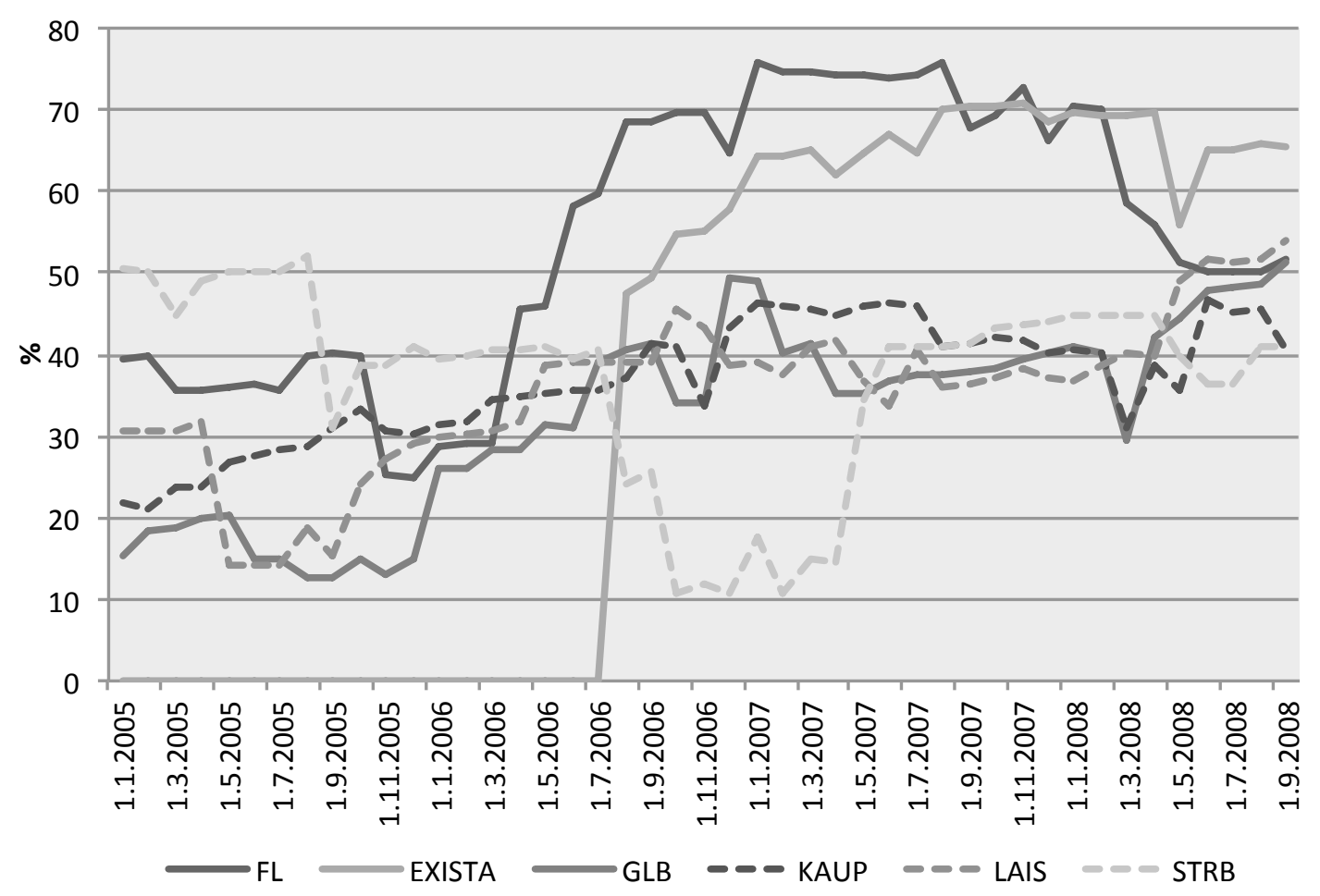

Mynd 2. Veð tekin af kauphallaraðilum, hlutfall útistandandi bréfa Heimild: RNA (Verðbréfaskráning Íslands).

„[K]ann pví að vakna grunur um að í einhverjum tilfellum hafi bankarnir leitast við að draga úr verðlækkunum eða á annan hátt að hafa áhrif á verðmyndun á hlutabréfum félaganna." (RNA, 4. bindi, bls. 61)

Pá rekur RNA einnig í löngu máli lánveitingar bankanna til hlutafjárkaupa, sérstaklega tímabilið frá ársbyrjun 2007 og fram að falli bankanna (sjá kafla 12.8, 4. bindi og kafla 8, 2. bindi). Mjög háar upphæðir voru lánaðar í pessu skyni. Raunar áttu pessar lánveitingar talsverðan pátt í pví mikla tapi sem við blasti eftir hrun bankanna pví að hið lánaða fé fæst í mörgum tilfellum ekki endurgreitt nema að litlum hluta, jafnvel engum, enda eignirnar, sem settar voru að veði, nú verðlitlar eða verðlausar.

Í ljósi niðurstaðna RNA um markaðsmisnotkun, sérstaklega er varðar hlutabréf banka, var skoðað í pessari rannsókn hvort pau sérkenni í ávöxtun á uppgjörstíma, sem fyrri rannsókn (Gylfi Magnússon, 2006) leiddi í ljós, hefðu komið fram með sama hætti síðustu misserin fyrir hrun og pau gerðu árin 2000 til 2006.

Skýrsla RNA varpar einnig talsverðu ljósi á próun hlutabréfamarkaðarins á uppgangstímanum, p.e. fram til ársins 2007. Ljóst er að fyrir tilstilli bankanna streymdi mikið lánsfé til Íslands og p.á m. inn á íslenska hlutabréfamarkaðinn. Petta flóð skýrði að verulegu leyti pá gríðarlegu hækkun á hlutabréfaverði sem varð, sérstaklega árin 2003 til 2005. Pá hækkaði raunverð hlutabréfa um meira en 50\% á ári, prjú ár í röð. ${ }^{6}$ Afleiðingarnar komu einnig fram á fasteignamarkaði, einkum frá og með árinu 2004, auk pess að hafa áhrif á gengi krónunnar. Mikið og vaxandi framboð á lánsfé ætti pó ekki eitt og sér að öðru jöfnu að búa

${ }^{6}$ Mikið framboð lánsfjár getur haft bein áhrif á eftirspurn eftir eignum, svo sem hlutabréfum, og pannig leitt til verðhækkunar. Ferlið er pó flóknara, verðhækkun eigna býr til hagnað á pappír hjá hluthöfum, sem stundum eru önnur hlutafélög, sem aftur getur leitt til verðhækkunar hlutabréfa og pannig koll af kolli. 
til pað sérkennilega mynstur í ávöxtun um mánaðamót eða ársfjórðungamót sem í ljós kom í fyrri rannsókn.

\section{5 Ávöxtun íslenskra hlutabréfa um mánaðamót}

Gylfi Magnússon (2006) sýndi fram á að fram til ársins 2006 höfðu íslensk hlutabréf hækkað að jafnaði meira síðasta viðskiptadag hvers mánaðar en á meðaldegi en lækkað síðan aftur fyrsta viðskiptadag hvers mánaðar. Frávikin frá meðalávöxtun reyndust enn meiri síðasta og fyrsta viðskiptadag hvers ársfjórðungs og mest pegar síðasti eða fyrsti viðskiptadagur hvers árs var skoðaður. Pessi sérkenni virtust mun meiri árin 2000 til 2006 en á upphafsárum markaðarins, 1993 til 1999. Fyrstu árin var engin merki pessara sérkenna að finna nema um áramót.

Í töflu 1 má sjá meðalávöxtun ${ }^{7}$ um pessi tímamót fyrir Úrvalsvísitöluna (ICEX-15) fram til ársloka 2008 og eftir pað arftaka hennar, OMXI6ISK, í báðum tilfellum án arðs. Einnig voru skoðaðar ávöxtunartölur fyrir sömu vísitölur með arði en pað skilaði nánast alveg sömu niðurstöðum og verður pví ekki sérstaklega fjallað um pær. Próun arðs var pó um margt áhugaverð, líkt og sjá má á mynd 5 (aftast) pótt hún breytti engu um sérkenni ávöxtunar um mánaðamót. Í töflu 2 má svo sjá meðalávöxtun alla daga fyrir ýmis tímabil, með og án arðs.

Eins og sjá má í töflu 1 var meðalávöxtun vísitölunnar síðasta viðskiptadag hvers mánaðar árin 2000 til 2006 0,35\%. Pá mánuði, sem einnig voru ársfjórðungamót, var meðalávöxtunin $0,71 \%$ síðasta daginn og síðasta viðskiptadag ársins var ávöxtunin $0,87 \%$. Til samanburðar var meðalávöxtun allra daga sama tímabil einungis 0,084\%. Árið 2007 og til miðs árs 2008, pegar fjármálakerfið var í nauðvörn, var ávöxtunin síðasta viðskiptadag hvers mánaðar talsvert lægri en á tímabilinu á undan (2000 til 2006) en pó jákvæð um 0,08\%.

Fyrsta viðskiptadag hvers mánaðar snúast pessar tölur svo við. Pá er ávöxtunin neikvæð, -0,31\%, árin 2000-2006 og enn neikvæðari á nauðvarnartímabilinu, -0,54\%. Sama mynstur sést um ársfjórðungamót. Ávöxtunin síðasta dag fyrir pau er jákvæð um 0,71\% árin 2000-2006 og neikvæð daginn eftir, -0,41\%. Á nauðvarnartímabilinu helst sama mynstur, sambærilegar tölur eru annars vegar $0,25 \%$ og hins vegar -0,52\%. Mynstrið virðist pví haldast óbreytt eftir 2006 og fram að hruni, munurinn á ávöxtun síðasta dag mánaðar og fyrsta dag mánaðar var 0,66\% árin 2000-2006 og 0,62\% 2007 og fyrri hluta 2008. Pó er rétt að benda á að niðurstöðurnar eru ekki tölfræðilega marktækar fyrir 2007 og fyrri hluta 2008 pótt meðaltölin bendi í sömu átt og áður. Út af fyrir sig er ekki skrýtið að erfitt sé að fá tölfræðilega marktækar niðurstöður fyrir petta tímabil í ljósi pess hve mikið gekk á og hve miklar sveiflur voru í hlutabréfaverði.

Mynstrið virðist við fyrstu sýn einnig haldast óbreytt fyrst eftir hrun. Á tímabilinu frá ársbyrjun 2009 til loka ársins 2011 er meðalávöxtun síðasta dags mánaðar 0,23\% og fyrsta dags mánaðar -0,24\%. Um ársfjórðungamót er niðurstaðan svipuð, 0,27\% annars vegar og hins vegar $-0,15 \%$. Um áramót eru frávikin aðeins meiri en um önnur ársfjórðungamót. Vegna pess hve um fá áramót er að ræða á peim tímabilum sem hér er horft sérstaklega til, p.e. 2007 til miðs árs 2008 annars vegar og eftir ársbyrjun 2009 hins vegar er pó vart hægt að draga miklar ályktanir af áramótatölunum.

\footnotetext{
${ }^{7}$ Reiknað er hefðbundið (arithmetic) meðaltal í öllum tilfellum.
} 
Tafla 1. Ávöxtun íslenskra hlutabréfa um mánaðamót, ársfjórðungsmót og áramót (án tillits til arðgreiðslna)

\begin{tabular}{lcc}
\hline & \multicolumn{2}{c}{ Mánaðamót } \\
& Fyrir & Eftir \\
\hline $1993-1999$ & $-0,02 \%$ & $-0,09 \%$ \\
$2000-2006$ & $0,35 \%$ & $-0,31 \%$ \\
$2007-2008: 2$ & $0,08 \%$ & $-0,54 \%$ \\
$2009-2011$ & $0,23 \%$ & $-0,24 \%$ \\
$2009-2011$ án útlaga & $0,03 \%$ & $-0,24 \%$ \\
$2010-2011$ & $0,08 \%$ & $-0,07 \%$ \\
\hline
\end{tabular}

\begin{tabular}{lcc} 
& \multicolumn{2}{c}{ Ársfjórðungsmót } \\
& Fyrir & Eftir \\
\hline $1993-1999$ & $0,04 \%$ & $-0,09 \%$ \\
$2000-2006$ & $0,71 \%$ & $-0,41 \%$ \\
$2007-2008: 2$ & $0,25 \%$ & $-0,52 \%$ \\
$2009-2011$ & $0,27 \%$ & $-0,15 \%$ \\
$2010-2011$ & $-0,09 \%$ & $0,03 \%$ \\
\hline
\end{tabular}

\begin{tabular}{lcc} 
& \multicolumn{2}{c}{ Áramót } \\
& Fyrir & Eftir \\
\hline $1993-1999$ & $0,30 \%$ & $-0,19 \%$ \\
$2000-2006$ & $0,87 \%$ & $-0,31 \%$ \\
$2007-2008: 2$ & $1,02 \%$ & $-0,94 \%$ \\
$2009-2011$ & $0,18 \%$ & $-0,46 \%$ \\
$2010-2011$ & $-0,39 \%$ & $-0,59 \%$ \\
\hline
\end{tabular}

\begin{tabular}{lcc} 
& \multicolumn{2}{c}{ Mánaðamót, ekki ársfjórðungamót } \\
& Fyrir & Eftir \\
\hline $1993-1999$ & $-0,06 \%$ & $-0,08 \%$ \\
$2000-2006$ & $0,17 \%$ & $-0,25 \%$ \\
$2007-2008: 2$ & $0,12 \%$ & $-0,60 \%$ \\
$2009-2011$ & $0,21 \%$ & $-0,29 \%$ \\
\hline
\end{tabular}

Nánari skoðun á gögnum frá árunum 2009 til 2011 leiðir pó í ljós að pað mynstur, sem hér hefur verið horft til, kom fyrst og fremst fram strax eftir hrun, p.e. árið 2009, en virtist að mestu horfið eftir pað.

Jafnframt skar ein mæling á árinu 2009 sig mjög úr, 29. maí, sem var síðasti viðskiptadagur pess mánaðar. Pá hækkaði hlutabréfavísitalan um 4,62\%. Síðasti dagur febrúar 2011 skar sig einnig nokkuð úr, pá hækkaði vísitalan um 2,97\%. Að pessum tveimur mælingum slepptum virtist fyrrnefnt mynstur að mestu eða alveg horfið eftir ársbyrjun 
Tafla 2. Ávöxtun íslenskra hlutabréfa frá upphafi

\begin{tabular}{ccc}
\hline \multicolumn{3}{c}{ Allir dagar, meðalávöxtun á dag. Án arðs. } \\
$\begin{array}{c}\text { Hefðbundið } \\
\text { (arithmetic) }\end{array}$ & $\begin{array}{c}\text { Margfeldis } \\
\text { (geometric) }\end{array}$ \\
\hline $1993-1999$ & $0,087 \%$ & $0,084 \%$ \\
$2000-2006$ & $0,084 \%$ & $0,079 \%$ \\
$2007-2008$ & $-0,416 \%$ & $-0,589 \%$ \\
$2007-2008: 2$ & $-0,100 \%$ & $-0,109 \%$ \\
$2009-2011$ & $0,000 \%$ & $-0,013 \%$ \\
$1993-2011$ & $0,019 \%$ & $-0,003 \%$ \\
\hline
\end{tabular}

Allir dagar, meðalávöxtun á ári (margfeldis). Án arðs.

Allir dagar, meðalávöxtun á ári (margfeldis).

\begin{tabular}{ccc}
\multicolumn{3}{c}{ Með arði. } \\
\hline & Nafn & Raun \\
$1993-1999$ & $26,3 \%$ & $23,2 \%$ \\
$2000-2006$ & $23,8 \%$ & $18,3 \%$ \\
$2007-2008$ & $-76,0 \%$ & $-78,6 \%$ \\
$2009-2011$ & $-2,9 \%$ & $-7,1 \%$ \\
$1993-2011$ & $1,0 \%$ & $-3,4 \%$ \\
\hline
\end{tabular}

2009. Án pessara útlaga er meðalávöxtun síðasta dags mánaðar árin 2009 til 2011 einungis 0,03\% og pað gefur enga ástæðu til að ætla að einhverjir hafi beitt sér fyrir pví að hækka verðið á peim tímamótum. Eftir stendur pó að ávöxtun fyrsta dags mánaðarins er talsvert undir meðaltali allra daga, -0,24\%. Рað frávik er pó ekki tölfræðilega marktækt. Pá er ávöxtun síðasta dags ársfjórðungs enn óvenjugóð $(0,27 \%)$ en neikvæð fyrsta dags ársfjórðungs (-0,15\%). Pau frávik eru pó ekki heldur tölfræðilega marktæk. Sé einungis horft

8 Pegar gengi bréfa í einstökum félögum er skoðað má sjá að hækkunina 29. maí 2009 má sérstaklega rekja til Alfesca en tilkynnt var um hluthafasamkomulag í félaginu pann dag og bréf pess hækkuðu um 23,5\%. Gengi bréfa í Marel og Össuri hækkaði einnig um annars vegar 5,1\% og hins vegar 3,4\% pennan dag. Gengi annarra bréfa lækkaði eða stóð í stað. 28. febrúar 2011 hækkuðu bréf í Össuri um 5,1\%, Icelandair um 3,4\% og Marel um 1,3\%. Pá hækkaði gengi Century Aluminum á tilboðsmarkaðinum um 3,1\%. Gengi annarra félaga stóð í stað. Pegar fá fyrirtæki eru skráð og velta lítil, raunar engin með sum félög, pá parf ekki mikla hreyfingu á verði í einstökum fyrirtækjum eða mikil viðskipti til að valda talsverðum breytingum á hlutabréfavísitölum. Í ljósi pessa verður að fara mjög varlega í að draga ályktanir af einstaka sveiflum í vísitölunum eftir hrun. 
Tafla 3. t-gildi fráviks

\begin{tabular}{lcc}
\hline & \multicolumn{2}{c}{ Mánaðamót } \\
& Fyrir & Eftir \\
\hline $1993-1999$ & $-1,31$ & $-2,25$ \\
$2000-2006$ & 2,66 & $-3,29$ \\
$2007-2008: 2$ & 0,73 & $-1,64$ \\
$2009-2011$ & 1,12 & $-1,63$ \\
\hline
\end{tabular}

\begin{tabular}{lcc} 
& \multicolumn{2}{c}{ Ársfjórðungamót } \\
& Fyrir & Eftir \\
\hline $1993-1999$ & $-0,33$ & $-1,48$ \\
$2000-2006$ & 4,21 & $-2,26$ \\
$2007-2008: 2$ & 0,71 & $-0,67$ \\
$2009-2011$ & 1,20 & $-0,57$ \\
\hline
\end{tabular}

til áranna 2010 og 2011, p.e. 2009 sleppt, pá virðist mynstrið einnig vera að mestu eða alveg horfið.

Раð væri óneitanlega athyglisvert ef að prátt fyrir hamfarirnar haustið 2008, sem gerbreyttu fjármálamarkaðinum íslenska, p.á m. hlutabréfamarkaðinum, pá myndu sérkenni í ávöxtun um mánaðamót birtast áfram í gögnunum eftir hrun, í grundvallaratriðum óbreytt frá pví fyrir hrun. Рað væri með nokkrum ólíkindum ef petta gerðist prátt fyrir að allir helstu pátttakendur á hlutabréfamarkaðinum hafi horfið, skráðum fyrirtækjum fækkað til muna, markaðsvirði hrunið og veltan dregist afar mikið saman. ${ }^{9}$ Ekki virðist pó ástæða til að álykta að fyrra mynstur sé enn til staðar, niðurstöðurnar eftir hrun hvað petta varðar eru fjarri pví að vera afgerandi og ekki tölfræðilega marktækar.

Staðalfrávik daglegrar ávöxtunar hefur breyst talsvert með tímanum. Á árunum 19931999 var pað að jafnaði um 0,72\%, jókst aðeins og var 0,87\% árin 2000 til 2005 en hækkaði síðan nokkuð, var 1,28\% árið 2006 og 1,18\% árið 2007. Árið 2008 sló pað öll met, sem kemur vart á óvart, og var 5,74\%. Árið 2009 var pað einnig allnokkuð eða 2,24\% en hefur síðan verið rétt undir einu prósenti.

Í ljósi pess hve mikil misdreifni er í ávöxtun á pví tímabili sem verið er að skoða og ávöxtun augljóslega ekki normaldreif ${ }^{10}$ eru hefðbundin $t$-gildi ekki góð vísbending um pað hvort frávik hafi verið marktæk. Pau voru pó reiknuð og eru birt í töflu 3, tölurnar miðast við Úrvalsvísitöluna fram til ársloka 2008 og eftir pað arftaka hennar, OMXI6ISK, án arðs.

Athyglisvert er að í öllum tilfellum í töflunni kemur fram óvenjuhá ávöxtun fyrir mánaðamót eða ársfjórðungamót og óvenjulág eftir sömu tímamót, frá og með 2000. t-gildin eru reiknuð skv. reiknireglunni:

9 Um mitt ár 2011 var markaðsverðmæti skráðra hlutabréfa í Kauphöll Ísland (Nasdaq OMX Íslandi) 274 milljarðar króna, sem er um 7,5\% pess sem mest var, í júlí 2007, að nafnvirði. Velta með bréfin hefur dregist enn meira saman, hlutfallslega.

${ }^{10}$ Fyrir öll pau tímabil, sem hér hafa verið til skoðunar, mælist reisn (kurtosis) vísitölunnar umtalsverð (pykkir halar) auk pess, sem dreifingin er alltaf skekkt (skewness) til vinstri nema á nauðvarnartímabilinu (2007 og fyrri hluta árs 2008) pegar hún er lítið eitt skekkt til hægri. Jarque-Bera próf staðfestir að pví fer fjarri að ávöxtun vísitölunnar sé normaldreifð, hvort heldur litið er á einstök tímabil eða allan tímann frá ársbyrjun 1993. 
Tafla 4. Líkur á fráviki í ávöxtun skv. MWW prófi

\begin{tabular}{lcccc}
\hline & \multicolumn{2}{c}{ Mánaðamót } & \multicolumn{2}{c}{ Ársfjórðungamót } \\
& Fyrir & Eftir & Fyrir & Eftir \\
\hline $2000-2006$ & $0,35 \%$ & $0,01 \%$ & $0,01 \%$ & $0,14 \%$ \\
$2007-2008: 2$ & $8,56 \%$ & $48,26 \%$ & $48,21 \%$ & $1,67 \%$ \\
$2009: 2011$ & $5,38 \%$ & $28,79 \%$ & $30,26 \%$ & $20,74 \%$ \\
\hline
\end{tabular}

$$
t_{d}=\frac{\bar{x}_{d}-\bar{x}_{\text {alls }}}{\sqrt{\frac{s_{d}^{2}}{n_{d}}+\frac{s_{\text {alls }}^{2}}{n_{\text {alls }}}}}
$$

Hér táknar $\bar{x}$ meðalávöxtun, $s$ staðalfrávik, $d$ vísar til viðkomandi tegundar dagsetningar (t.d. síðasti viðskiptadagur hvers mánaðar) og $n$ er fjöldi mælinga fyrir sambærilega daga. Vegna pess að ávöxtun er ekki normaldreifð verður að túlka $t$-gildin varlega. Vegna pessa var einnig beitt Mann-Whitney-Wilcoxon (MWW) prófi en pað reiðir sig ekki á normaldreifingu sem forsendu. Reiknaðar voru út líkur á hverju fráviki fyrir sig skv. prófinu, p.e. líkur á að fá pennan mun á úrtaksmeðaltali ef raunverulegt meðaltal ávöxtunar væri hið sama alla daga. Niðurstöðurnar eru birtar í töflu $4 .{ }^{11}$

Niðurstöðurnar í töflu 4 gefa svipaðar vísbendingar og tafla 3. Frávikin, sem fundust árin 2000 til 2006, eru vel tölfræðilega marktæk. Hin tvö tímabilin, p.e. árið 2007 og fyrri hluta 2008 annars vegar og frá ársbyrjun 2009 til miðs árs 2011 hins vegar, sjást svipuð frávik en pau eru hins vegar almennt ekki tölfræðilega marktæk og sum raunar langt frá pví. Hér er rétt að hafa í huga аð pað hve mælingar eru tiltölulega fáar og gríðarlegar sveiflur á markaðinum, sérstaklega rétt fyrir hrun en einnig að nokkru marki eftir hrun, veldur pví að erfitt er að fá tölfræðilega marktækar niðurstöður. ${ }^{12}$

Á mynd 3 má sjá dreifingu ávöxtunar OMXI6ISK vísitölunnar um mánaðamót frá ársbyrjun 2009 til ársloka 2011.

Í töflum 6 og 7 (aftast) má sjá yfirlit um ávöxtun hlutabréfa einstakra fyrirtækja um sömu tímamót, annars vegar árið 2007 og fyrri hluta árs 2008 og hins vegar frá ársbyrjun 2009 til ársloka 2011. Miðað er við öll fyrirtæki sem voru skráð í Kauphöllina. Athygli er vakin á pví аð meðaltölin eru ekki fyllilega sambærileg vegna pess hve mislengi fyrirtækin hafa verið skráð í Kauphöllina.

${ }^{11}$ Vel er pekkt að flökt á fjármálamörkuðum breytist yfir tíma. Pað á einnig við hér. Vegna pessa hefði einnig verið hugsanlegt að beita öðrum prófum, sem gera ráð fyrir misdreifni, á pau gögn sem hér eru til skoðunar. Sjá t.d. umfjöllun um önnur próf í (Alt, Fortin og Weinberger, 2011). Pað verður pó ekki gert hér enda virðist MWW eiga vel við pau gögn sem hér er stuðst við og niðurstöðurnar mjög skýrar og afdráttarlausar fyrir tímabilið frá aldamótum og fram að hruni. Раð væri efni í sjálfstæða grein að leggja mat á skilvirkni hinna ýmsu tölfræðiprófa sem til greina koma en yrði væntanlega gert með hermilíkani með tilbúnum gögnum (Monte Carlo) en ekki raunverulegum gögnum eins og peim, sem hér er unnið með.

${ }^{12}$ Sveiflur eru almennt minni eftir hrun en í darraðadansinum í aðdraganda hrunsins. Pó koma einstaka mjög skrýtnir dagar. Pannig lækkaði OMXI6ISK vísitalan um nær 27\% 9. mars 2009 við fall Straums. 


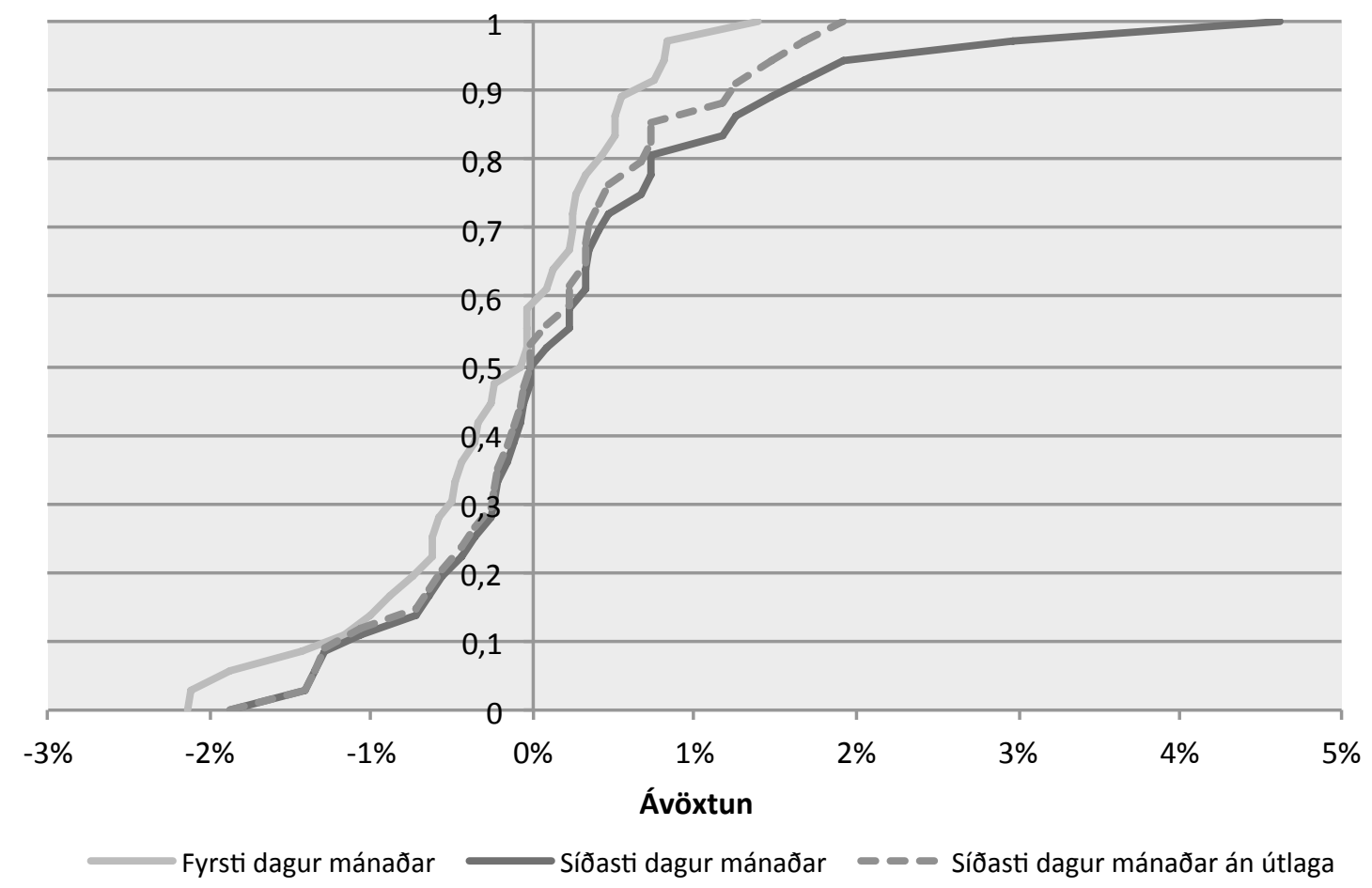

Mynd 3. Péttifall ávöxtunar við mánaðamót 2009 - 2011

Í töflu 6 má sjá nokkuð skýrar vísbendingar um að frávik í ávöxtun Úrvalsvísitölunnar um fyrrgreind tímamót er ekki hægt að rekja til viðskipta með fá fyrirtæki í aðdraganda hrunsins pví að svipað mynstur lýsir einnig verðpróun einstakra fyrirtækja í mörgum tilfellum. Pannig sést t.d. að meira en prefalt fleiri fyrirtæki lækka í verði daginn eftir (20) áramót en daginn fyrir (6). Hið öfuga gildir um hækkun, meira en tvöfalt fleiri hækka (15) daginn fyrir áramót en daginn eftir (7). Vegna pess að einungis er um ein áramót að ræða er varhugavert að draga sterkar ályktanir af pví einu en svipað mynstur sést um bæði ársfjórðungamót og mánaðamót.

Myndin er ekki jafnskýr í töflu 7, sem byggir á gögnum frá pví eftir hrun. Pað styður pá niðurstöðu sem fékkst við skoðun á vísitölunni að mynstrið, sem einkenndi ávöxtun um mánaðamót fyrir hrun, hafi ekki verið mjög áberandi, ef pað var pá yfirhöfuð til staðar, eftir hrun.

Próun hlutabréfamarkaðarins frá miðju ári 2007 og fram að hruni einkenndist, sem fyrr segir, af nær stöðugri lækkun hlutabréfaverðs. Pó komu stutt tímabil inn á milli par sem verð hækkaði, eins og sjá má á mynd 4. Athyglisvert er að skoða dagsetningar í pessu samhengi og eru niðurstöðurnar dregnar saman í töflu 5, sem sýnir yfirlit um lok helstu hækkunarhrina, ${ }^{13}$ sem urðu til að stöðva tímabundið pá miklu lækkun sem annars varð á íslenska markaðinum frá miðju ári 2007 og pangað til bankakerfið hrundi. Ekki er hægt að sjá neitt sérstakt mynstur út úr pessum dagsetningum og pótt tvær peirra endi rétt fyrir mánaðamót pá er vart ástæða til að draga neinar sérstakar ályktanir út frá pví.

${ }^{13}$ Hækkunarhrina var hér skilgreind pannig að vísitalan uppfyllti prjú skilyrði, sem hér segir: 1) Vísitalan væri hærri en hæsta gildi síðustu 5 daga á undan. 2) Vísitalan væri meira en 1\% hærri en fimm dögum áour. 3) Næsta hækkunarhrina hæfist meira en tveimur dögum síðar. 


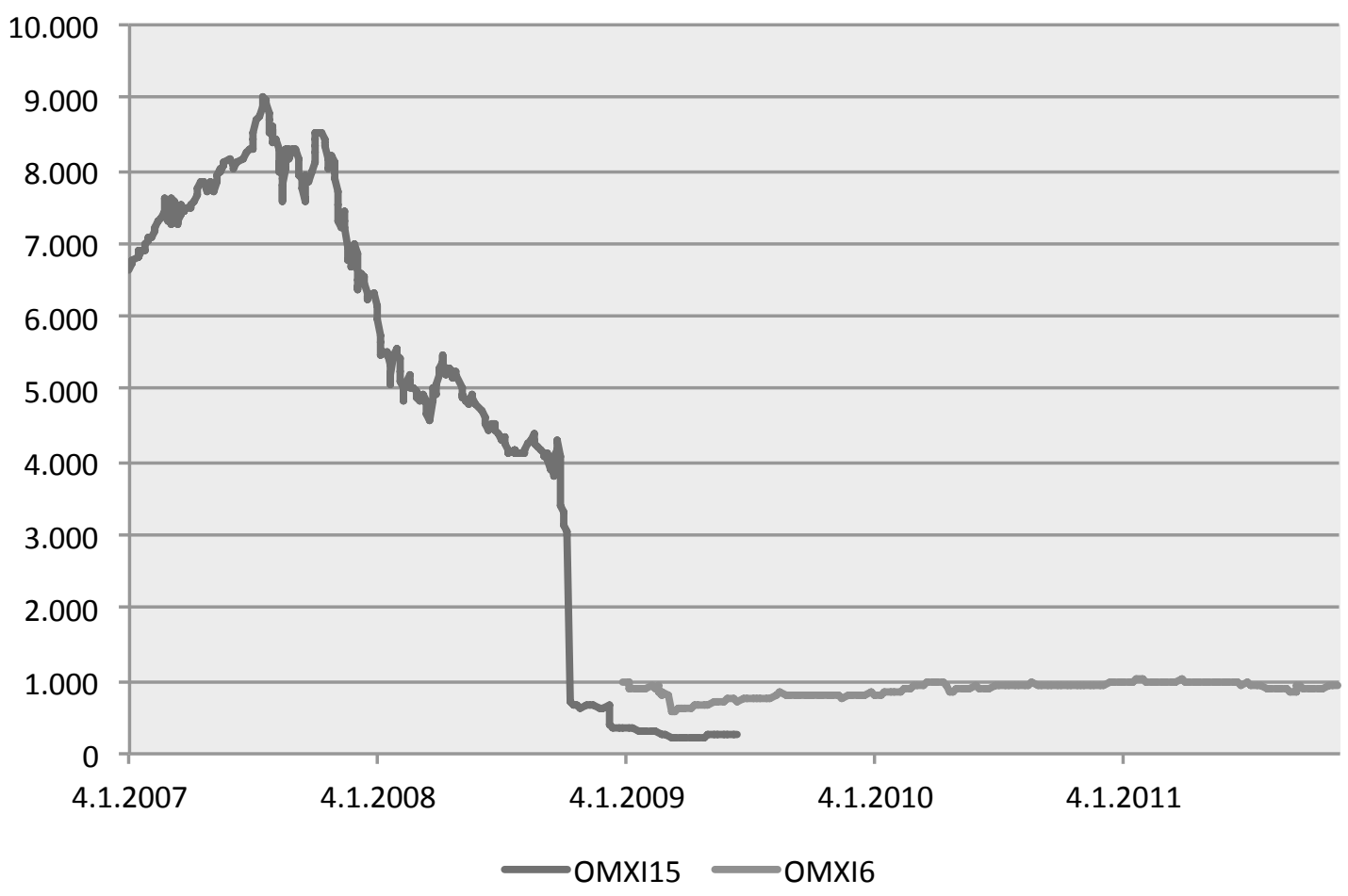

Mynd 4. Próun OMXI15 og OMXI6ISK 2007 - 2011

Tafla 5. Lok helstu hækkanahrina í aðdraganda hruns

\begin{tabular}{cc}
\hline Dagsetning & 23.8 .2007 \\
- & 11.10 .2007 \\
- & 30.11 .2007 \\
- & 29.1 .2008 \\
- & 18.2 .2008 \\
- & 12.3 .2008 \\
- & 9.4 .2008 \\
- & 25.6 .2008 \\
- & 18.8 .2008 \\
\hline
\end{tabular}

\section{6 Ályktanir og lokaorð}

Enginn vafi leikur á pví að mánaðamót, og pó sérstaklega ársfjórðunga- eða áramót, voru óvenjulegur tími á íslenskum hlutabréfamarkaði, a.m.k. frá aldamótum og fram að hruni. Verðpróun á pessum tímamótum var verulega frábrugðin pví sem almennt gerðist á markaðinum. Pessi munur virðist ekki hafa verið til staðar á fyrstu árum markaðarins, fyrir síðustu aldamót. Hann er hins vegar skýr frá árinu 2000 og fram að hruni fjármálamarkaðarins í október 2008. Ekki eru skýrar vísbendingar um að mynstrið haldi áfram eftir endurreisn markaðarins, p.e. frá og með ársbyrjun 2009. Vegna pess hve stuttur tími er liðinn er pó vart hægt að fullyrða meira en að tíminn muni leiða betur í ljós hvort 
mynstrið hefur í raun lifað af pær miklu sviptingar sem orðið hafa á íslenskum fjármálamarkaði undanfarin ár. Fyrstu vísbendingar benda pó til pess að svo sé ekki.

Ekki liggur að fullu fyrir hver skýring pessa mynsturs er. Í fyrri rannsókn (Gylfi Magnússon, 2006) var bent á að pað að mikil hækkun fyrir ársfjórðungamót skuli koma fram að morgni síðasta viðskiptadags bendi ekki sérstaklega til pess að einhverjir séu vísvitandi að reyna að ýta dagslokaverði upp. Við slíkum viðskiptum væri einkum að búast síðari hluta dags, jafnvel rétt fyrir lokun. Pó væri hugsanlegt að tímasetningarnar innan dags væru einmitt valdar með hliðsjón af pví að ná fram verðhækkun á tilteknum tíma án pess að vekja athygli eftirlitsaðila.

Síðan fyrri grein var skrifuð hafa komið fram skýrar vísbendingar um umfangsmikla markaðsmisnotkun á íslenska hlutabréfamarkaðinum í aðdraganda hruns, sérstaklega í skýrslu RNA. Í ljósi pess er hægt að fullyrða að mjög miklar líkur séu á pví að rekja megi petta mynstur í ávöxtun fyrr á árum til tilhneigingar stórra markaðsaðila til að ýta hlutabréfaverði upp skömmu fyrir uppgjör. •að væri í góðu samræmi við almenna viðleitni peirra til að halda uppi verði tiltekinna hlutabréfa enda skiptir pað alla jafna meiru hvert skráð verð hlutabréfa og annarra eigna er á uppgjörstíma en á öðrum tímum. Í aðdraganda hrunsins varð pó vandi vegna veðkalla sífellt verri við að eiga, p.e. sífellt lækkandi markaðsverð eigna í krónum og gengisfall krónunnar leiddi til pess að veðpekja varð ónóg. Við pær aðstæður skipta dagsetningar eins og mánaðamót eða ársfjórðungamót ekki höfuðmáli. Раð getur hugsanlega skýrt að einhverju marki hvers vegna síðustu fjörkippir hlutabréfamarkaðarins urðu ekki á slíkum tímamótum, sbr. töflu 7.

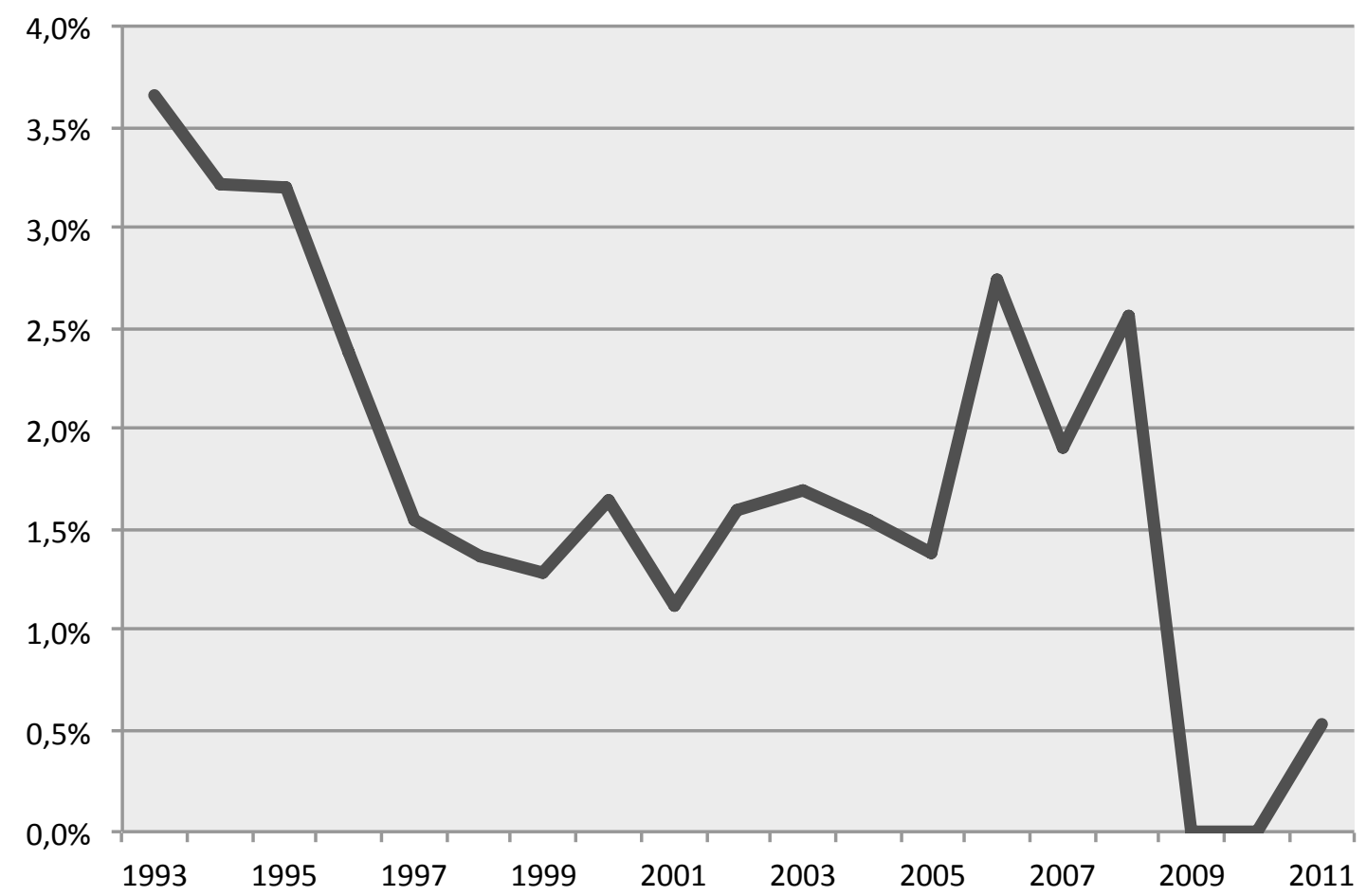

Mynd 5. Arðshlutfall (dividend yield)

OMX-15 (Úrvalsvísitala) fram til ársloka 2008 og OMXI6ISK eftir pað. 
Tafla 6. Ávöxtun dagana fyrir og eftir mánaðamót

Frá ársbyrjun 2007 til miðs árs 2008.

\begin{tabular}{|c|c|c|c|c|c|c|c|c|c|}
\hline & \multicolumn{3}{|c|}{ Áramót } & \multicolumn{3}{|c|}{ Ársfjórðungamót } & \multicolumn{3}{|c|}{ Mánaðamót } \\
\hline & Fjöldi & Fyrir & Eftir & Fjöldi & Fyrir & Eftir & Fjöldi & Fyrir & Eftir \\
\hline 365 & 1 & $0,48 \%$ & $-2,03 \%$ & 5 & $0,19 \%$ & $0,51 \%$ & 17 & $-0,26 \%$ & $-0,58 \%$ \\
\hline A & 1 & $0,43 \%$ & $-0,05 \%$ & 5 & $0,51 \%$ & $0,07 \%$ & 17 & $0,21 \%$ & $0,06 \%$ \\
\hline $\mathrm{ACT}$ & 0 & & $1,25 \%$ & 2 & $-0,33 \%$ & $0,42 \%$ & 7 & $-0,44 \%$ & $0,26 \%$ \\
\hline ATOR & 1 & $0,10 \%$ & $0,49 \%$ & 5 & $0,03 \%$ & $0,19 \%$ & 17 & $-0,17 \%$ & $0,19 \%$ \\
\hline BAKK & 1 & $0,69 \%$ & $-0,21 \%$ & 5 & $0,48 \%$ & $0,14 \%$ & 17 & $-0,66 \%$ & $-0,23 \%$ \\
\hline CENX & 1 & $-1,01 \%$ & $-1,90 \%$ & 4 & $-0,54 \%$ & $0,32 \%$ & 12 & $0,41 \%$ & $0,52 \%$ \\
\hline EXISTA & 1 & $0,77 \%$ & $-3,04 \%$ & 5 & $0,68 \%$ & $-0,47 \%$ & 17 & $0,21 \%$ & $-0,36 \%$ \\
\hline FL & 1 & $0,21 \%$ & $-1,08 \%$ & 5 & $0,39 \%$ & $-0,26 \%$ & 17 & $-0,11 \%$ & $-0,68 \%$ \\
\hline FLAGA & 1 & $0,00 \%$ & $0,00 \%$ & 5 & $-0,27 \%$ & $0,65 \%$ & 17 & $-1,08 \%$ & $-0,73 \%$ \\
\hline FO-AIR & 1 & $-1,08 \%$ & $-2,61 \%$ & 2 & $-0,28 \%$ & $-1,05 \%$ & 6 & $-0,23 \%$ & $-0,90 \%$ \\
\hline FO-ATLA & 1 & $-0,90 \%$ & $1,76 \%$ & 5 & $-1,37 \%$ & $2,98 \%$ & 17 & $-0,49 \%$ & $1,19 \%$ \\
\hline BNORDIK & 1 & $2,23 \%$ & $-6,56 \%$ & 4 & $0,96 \%$ & $-2,73 \%$ & 12 & $0,74 \%$ & $-1,14 \%$ \\
\hline FO-EIK & 1 & $3,59 \%$ & $-0,19 \%$ & 3 & $-0,50 \%$ & $1,26 \%$ & 11 & $-0,47 \%$ & $-0,19 \%$ \\
\hline GLB & 1 & $-0,23 \%$ & $-0,39 \%$ & 5 & $0,30 \%$ & $-0,21 \%$ & 17 & $0,17 \%$ & $-0,28 \%$ \\
\hline GRND & 1 & $0,00 \%$ & $-2,20 \%$ & 5 & $0,00 \%$ & $2,60 \%$ & 17 & $0,00 \%$ & $0,97 \%$ \\
\hline HAMP & 1 & $0,00 \%$ & $0,00 \%$ & 5 & $0,00 \%$ & $0,12 \%$ & 17 & $0,42 \%$ & $0,04 \%$ \\
\hline HFEIM & 1 & $-0,14 \%$ & $-0,67 \%$ & 5 & $-1,23 \%$ & $-1,10 \%$ & 17 & $-0,78 \%$ & $-1,01 \%$ \\
\hline ICEAIR & 1 & $2,40 \%$ & $-0,90 \%$ & 5 & $1,70 \%$ & $-1,21 \%$ & 17 & $0,40 \%$ & $-0,47 \%$ \\
\hline IG & 1 & $0,00 \%$ & $-0,19 \%$ & 5 & $-2,08 \%$ & $-0,72 \%$ & 17 & $-2,64 \%$ & $-1,35 \%$ \\
\hline KAUP & 1 & $0,11 \%$ & $-0,80 \%$ & 5 & $0,98 \%$ & $0,23 \%$ & 17 & $0,44 \%$ & $-0,39 \%$ \\
\hline LAIS & 1 & $0,42 \%$ & $0,96 \%$ & 5 & $0,18 \%$ & $0,40 \%$ & 17 & $0,11 \%$ & $-0,13 \%$ \\
\hline MARL & 1 & $0,49 \%$ & $-0,16 \%$ & 5 & $0,49 \%$ & $-0,18 \%$ & 17 & $0,11 \%$ & $-0,04 \%$ \\
\hline MOSAIC & 0 & & $-1,31 \%$ & 3 & $-0,98 \%$ & $0,58 \%$ & 9 & $-0,55 \%$ & $0,85 \%$ \\
\hline NYHR & 1 & $0,00 \%$ & $0,68 \%$ & 5 & $0,50 \%$ & $-0,38 \%$ & 17 & $0,15 \%$ & $0,01 \%$ \\
\hline OSSR & 1 & $0,31 \%$ & $0,56 \%$ & 5 & $0,29 \%$ & $-0,01 \%$ & 17 & $-0,12 \%$ & $-0,29 \%$ \\
\hline SFS B & 1 & $0,00 \%$ & $0,00 \%$ & 5 & $2,14 \%$ & $1,23 \%$ & 17 & $0,03 \%$ & $0,25 \%$ \\
\hline SKIPTI & 0 & & & 1 & $-1,57 \%$ & $0,80 \%$ & 3 & $0,18 \%$ & $0,27 \%$ \\
\hline SPRON & 1 & $1,78 \%$ & $-5,81 \%$ & 2 & $1,13 \%$ & $-3,14 \%$ & 8 & $0,90 \%$ & $-0,97 \%$ \\
\hline STRB & 1 & $-0,98 \%$ & $-0,33 \%$ & 5 & $0,08 \%$ & $0,37 \%$ & 17 & $0,05 \%$ & $-0,16 \%$ \\
\hline TEYMI & 1 & $1,37 \%$ & $2,01 \%$ & 5 & $0,17 \%$ & $0,41 \%$ & 17 & $-0,33 \%$ & $-0,09 \%$ \\
\hline $\mathrm{TM}$ & 1 & $0,00 \%$ & $-0,80 \%$ & 5 & $-0,05 \%$ & $-0,48 \%$ & 17 & $0,02 \%$ & $-0,12 \%$ \\
\hline VNST & 1 & $0,00 \%$ & $0,00 \%$ & 5 & $0,00 \%$ & $0,38 \%$ & 17 & $0,22 \%$ & $0,30 \%$ \\
\hline Neikvæð & & 6 & 20 & & 11 & 13 & & 14 & 20 \\
\hline Jákvæð & & 15 & 7 & & 18 & 19 & & 17 & 12 \\
\hline Núll & & 8 & 4 & & 3 & 0 & & 1 & 0 \\
\hline
\end{tabular}


Tafla 7. Ávöxtun dagana fyrir og eftir mánaðamót Frá áramótum 2008/2009 til áramóta 2011/2012.

\begin{tabular}{|c|c|c|c|c|c|c|c|c|c|}
\hline \multirow[b]{3}{*}{ A } & \multicolumn{3}{|c|}{ Áramót } & \multicolumn{3}{|c|}{ Ársfjórðungamót } & \multicolumn{3}{|c|}{ Mánaðamót } \\
\hline & Fjöldi & Fyrir & Eftir & Fjöldi & Fyrir & Eftir & Fjöldi & Fyrir & Eftir \\
\hline & 0 & & $0,00 \%$ & 4 & $0,61 \%$ & $0,00 \%$ & 9 & $2,19 \%$ & $-0,33 \%$ \\
\hline BAKK & 1 & $2,56 \%$ & $0,80 \%$ & 6 & $1,13 \%$ & $-0,23 \%$ & 15 & $0,82 \%$ & $-0,68 \%$ \\
\hline CENX & 3 & $-1,35 \%$ & $5,46 \%$ & 13 & $-1,71 \%$ & $2,17 \%$ & 36 & $-0,87 \%$ & $2,60 \%$ \\
\hline FO-AIR & 3 & $0,29 \%$ & $0,00 \%$ & 13 & $-0,09 \%$ & $0,28 \%$ & 36 & $-0,03 \%$ & $0,02 \%$ \\
\hline FO-ATLA & 3 & $3,35 \%$ & $3,91 \%$ & 13 & $1,20 \%$ & $0,85 \%$ & 36 & $-0,12 \%$ & $-0,51 \%$ \\
\hline BNORDIK & 3 & $0,00 \%$ & $-0,09 \%$ & 13 & $0,11 \%$ & $0,02 \%$ & 36 & $0,01 \%$ & $0,32 \%$ \\
\hline FO-EIK & 1 & $-2,44 \%$ & $1,09 \%$ & 8 & $-2,90 \%$ & $0,12 \%$ & 23 & $-0,10 \%$ & $-1,00 \%$ \\
\hline GRND & 3 & $0,00 \%$ & $0,00 \%$ & 13 & $0,00 \%$ & $0,00 \%$ & 36 & $0,85 \%$ & $-0,14 \%$ \\
\hline HAMP & 3 & $0,00 \%$ & $0,00 \%$ & 13 & $0,00 \%$ & $-0,30 \%$ & 36 & $0,00 \%$ & $-0,42 \%$ \\
\hline HFEIM & 0 & & $-1,60 \%$ & 3 & $0,00 \%$ & $-0,53 \%$ & 6 & $-1,67 \%$ & $-0,09 \%$ \\
\hline ICEAIR & 3 & $-3,36 \%$ & $0,64 \%$ & 13 & $0,26 \%$ & $0,05 \%$ & 36 & $0,19 \%$ & $0,02 \%$ \\
\hline MARL & 3 & $-1,02 \%$ & $-0,54 \%$ & 13 & $0,06 \%$ & $0,29 \%$ & 36 & $0,37 \%$ & $0,14 \%$ \\
\hline NYHR & 3 & $-1,68 \%$ & $0,00 \%$ & 13 & $-0,58 \%$ & $-0,37 \%$ & 36 & $0,01 \%$ & $-0,13 \%$ \\
\hline OSSR & 3 & $-0,69 \%$ & $-1,58 \%$ & 13 & $0,28 \%$ & $-0,52 \%$ & 36 & $0,23 \%$ & $-0,41 \%$ \\
\hline SFS B & 3 & $0,00 \%$ & $0,00 \%$ & 13 & $0,00 \%$ & $0,00 \%$ & 36 & $0,00 \%$ & $0,00 \%$ \\
\hline STRB & 0 & & $0,54 \%$ & 1 & $5,08 \%$ & $0,54 \%$ & 2 & $-1,18 \%$ & $-2,21 \%$ \\
\hline Neikvæð & & 6 & 4 & & 4 & 5 & & 6 & 10 \\
\hline Jákvæð & & 3 & 6 & & 8 & 8 & & 8 & 5 \\
\hline Núll & & 4 & 6 & & 4 & 3 & & 2 & 1 \\
\hline
\end{tabular}




\section{Heimildir}

Alt, Raimund, Fortin, Ines og Weinberger, Simon. (2011). The Monday effect revisited: An alternative testing approach. Journal of Empirical Finance. 3/18, 447-460.

Chee-Jiun, Chia R. og Ye, Lim Shiok. (2011). Stock Market Anomalies in South Africa and its Neighbouring Countries. Economics Bulletin. 4/31, 3123-3137.

Fields, M. (1931). Stock Prices: A Problem in Verification. Journal of Business. 4/4. 415-418.

Gylfi Magnússon. (2006). Ávöxtun íslenskra hlutabréfa á uppgjörstíma. Tímarit um viðskipti og efnahagsmál. 4, 87-113.

Hæstaréttardómur 52/2010.

Kauphöll Íslands. (2006). Hvenær hækkar Úrvalsvísitalan? Höfundur ótilgreindur. Kauphallartídindi, 6. september, 17. tbl. 6. árg.

Kelly, Fred C. (1930). Why You Win or Lose. Houghton-Mifflin. Boston.

Maberly, Edwin D. (1995). Eureka! Eureka! Discovery of the Monday Effect Belongs to the Ancient Scribes. Financial Analysts Journal. 5/51, 10-11.

McConnell, John J. og Wei Xu. (2008), Equity Returns at the Turn of the Month. Financial Analyst Journal. 2/64, 49-64.

Páll Hreinsson, Sigríður Benediktsdóttir og Tryggvi Gunnarsson. (2010). Aðdragandi og orsakir falls íslensku bankanna 2008 og tengdir atburđir. Rannsóknarnefnd Alpingis. Reykjavík.

Pettengill, Glenn N. (2003). A Survey of the Monday Effect Literature. Quarterly Journal of Business \& Economics. 3-4/42. 3-27.

Sharma, Susan S. og Narayan, Paresh K. (2011). The January and turn-of-the-month effect on firm returns and return volatility. Financial Econometric Series, Deakin University. SWP 2011/01.

Stefán B. Gunnlaugsson. (2003). Er samband á milli daga, mánaða, hátíða og ávöxtunar á íslenskum hlutabréfamarkaði? Tímarit um viðskipti og efnahagsmál, 1, 73-88.

Vísbending. (2006). Er svindlað á hlutabréfamarkaði? Höfundur ótilgreindur. Vísbending, 29. september, 37. tbl. 24. árg. 